https://doi.org/10.52058/2786-4952-2021-5(5)-491-501

Молчанова Еллана Юріївна кандидат економічних наук, доцент, доцент кафедри міжнародного менеджменту Київського національного торговельноекономічного університету, вул. Ю.Шевелева 49/20, кв.18, м. Київ, 02099, тел.: (067) 274-93-85, e-mail: ellanam@ukr.net, https://orcid.org/0000-0001-8043-1916

Руденко Андрій Олександрович студент другого курсу другого (магістерського) рівня навчання, Київський національний університет будівництва та архітектури, 02218, Київ, проспект Романа Шухевича 2, кв. 75, тел.: (063) 749-04-61, e-mail: andrey.rrudenko@gmail.com, https://orcid.org/00000001-9160-7315

\title{
ПОБУДОВА МОДЕЛІ ІНКЛЮЗИВНОГО НАВЧАННЯ В ЗАКЛАДАХ ВИЩОї ОСВІТИ
}

Анотація. В статті проаналізовані основні кроки формування інклюзивної освіти в України на законодавчому рівні. Виявлена певна послідовність формування законодавчої бази, повільність впровадження юридичних ініціатив, відставання від досвіду європейських країн. Також виявлена незначна фінансова підтримка розвитку «інклюзивної освіти» в Україні. Використані результати соціологічного дослідження, яке дозволило сформувати уявлення про готовність дітей з особливими потребами здобувати вищу освіту, а їх батьків підтримувати дітей. Проаналізовані заходу з боку міністерства освіти та науки щодо створення системи інклюзивного навчання для дітей віком від 2-х до 18-ти років на базі ресурсно-інклюзивних центів. Проаналізовані основні онлайн платформи, виявлені їх особливості та наведений перелік основних курсів. Виявлено, що лише дві платформи використовують технології адаптивного навчання. Під час аналізу було 3'ясовано, що представлені окремі курси на платній та безоплатній основі, але не представлені заклади вищої освіти, окремі курси мають елементи «інклюзивності», але жодний курс для студентів не містить адаптивних технологій. Окремі курси розміщаються на youtube-каналі, на якому дозволяється використовувати сурдопереклад. Запропонована модель формування онлайн платформи, яка закладає основи формування нового стандарту до розробки освітніх курсів, нової методології, форм взаємодії між студентами, між студентами та викладачами. Ця модель також передбачає використовувати неформальну світу, а закладам вищої освіти, які приймають участь у наповненні платформи - використовувати іiі результати в формальній освіті. Також ця платформа дозволить опановувати курсі, які пропонують представники інших закладів вищої освіти. 
Журнал «Герспективитаінноваціїнауки»

(Серія«Гедагогіка»), Серія«ГТихологія», Серія «Медицина»

№5(5) 2021

Ключові слова: інклюзивна освіта, діти з особливими потребами, онлайн освітні платформи, «інклюзивність».

Molchanova Ellana Yuriyivna Candidate of Economic Sciences, Associate Professor, Associate Professor of the Department of International Management, Kyiv National University of Trade and Economics, 49/20 Yu.Sheveleva St., Apt.18, Kyiv, 02099, тел.: (067) 274-93-85, e-mail: ellanam@ukr.net, https://orcid.org/0000-00018043-1916

Rudenko Andriy Oleksandrovych Second-year student of the second (master's) level of education, Kyiv National University of Civil Engineering and Architecture, 2, Roman Shukhevych Ave., Apt. 75, Kyiv, 02218, tel.: (063) 749-04-61, e-mail: andrey.rrudenko@gmail.com, https://orcid.org/0000-0001-9160-7315

\section{CREATING A MODEL OF INCLUSIVE EDUCATION IN HIGHER EDUCATION INSTITUTIONS}

Abstract. The article analyses the main steps in the formation of inclusive education in Ukraine at the legislative level. There is a certain sequence of formation of the legal framework, slow implementation of legal initiatives, lagging behind the experience of European countries. There was also little financial support for the development of "inclusive education" in Ukraine. The results of a sociological research were used, which allowed to form an idea of the readiness of children with special needs to obtain higher education, and their parents to support children. The measures of the Ministry of Education and Science to create an inclusive education system for children aged 2 to 18 on the basis of resource-inclusive centres are analysed. The main online platforms are analyzed, their features are identified and the list of basic courses is given. It was found that only two platforms use adaptive learning technologies. The analysis revealed that some courses are available on a paid and free basis, but no higher education institutions are represented, some courses have elements of "inclusiveness", but no course for students contains adaptive technologies. Some courses are posted on the you tube channel, which allows the use of sign language translation. A model of online platform formation is proposed, which lays the foundations for the formation of a new standard for the development of educational courses, new methodology, forms of interaction between students, between students and teachers. This model also involves the use of the nonformal world, and higher education institutions involved in filling the platform to use its results in formal education. This platform will also allow you to master the courses offered by representatives of other higher education institutions.

Keywords: inclusive education, children with special needs, online educational platforms, inclusiveness.

Постановка проблеми. Розвиток інформаційних технологій, занурення молоді в діджитал світ, формування глобального інформаційного суспільства 492 
висуває нові вимоги до освіти. На перший план освітньої парадигми виходять питання реалізації прав дітей та можливості їх самореалізації. Окремим важливим питанням, що потребує вирішення, $\epsilon$ навчання, соціалізація й самореалізація дітей 3 обмеженими можливостями та формування інклюзивного освітнього середовища.

Аналіз останніх досліджень та публікацій. Дослідження інклюзії посіло значне місце в дослідження науковців педагогічних наук. Більшість українських досліджень спрямовані на освітні методології інклюзивного навчання та висвітлені в працях Г. Давиденко, О. Ільїної, А. Колупаєвої, О. Мартинової, С. Миронової, О. Миськів, О. Мовчан, О. Полякової, Т. Самсонової, Н. Софій, О. Столяренко, В. Синьової, П. Таланчука, Є. Тарасенко, Н. Шаповала, А. Шевцова тощо. Проте майже відсутні дослідження онлайнових форм реалізації інклюзивної форми навчання, що підвищує актуальність окресленої проблеми, свідчить про ऑiі недостатню розробленість у теорії і практиці соціальної роботи, необхідність подолання існуючих перешкод на шляху впровадження інклюзії.

Мета статті. Метою дослідження є обгрунтування необхідності побудови моделі інклюзивного навчання в Україні на рівні вищої освіти.

Виклад основного матеріалу. Інклюзивна освіта $є$ складовою сучасної державної політики кожної держави. Саме існування інклюзивної освіти свідчить про захист невід'ємного права людини на здобуття освіти. Одним із ключових напрямків спільної ініціативи є експертне забезпечення розробки та реалізації ефективної державної політики у сфері інклюзивної освіти в Україні. Ефективність інклюзивної освіти залежить насамперед від готовності держави прийняти відповідне законодавство, чітко визначити напрями політики, розробити план дій, розбудовувати інфраструктуру, а також потенціал для впровадження та отримати вигоду від довгострокового фінансування. Основною проблемо інклюзивної освіти $є$ відсутність механізму іiі впровадження на всіх рівнях системи освіти, та регулювання субститутів. Ратифікації Україною Конвенції ООН про права людей з інвалідністю [1] стала першим кроком на шляху впровадження законодавчого регулювання інклюзивної освіти в Україні. Першими документами стали Розпорядження Кабінету Міністрів України «Про затвердження планів заходів щодо впровадження інклюзивної та інтегрованої освіти в загальноосвітніх навчальних закладах на період до 2012 року» [2] та Наказ МОН «Про затвердження плану заходів щодо впровадження інклюзивної освіти в загальноосвітніх навчальних закладах на 2009-2012 роки» [3]. Ці пілотні проєкти висвітлили необхідність наукового обгрунтування створення програм, методичного забезпечення, підготовки та перепідготовки педагогічних кадрів для роботи 3 дітьми особливими потребами та їх батьками в умовах інклюзивної освіти. Постановою КМУ «Про затвердження Порядку організації інклюзивного навчання у загальноосвітніх навчальних закладах» були визначені основи обов'язкового здобуття середньої освіти. Сьогодні ще залишаються невирішеними проблеми доступності освітніх закладів, готовності педагогічної спільноти до роботи 3 дітьми 3 особливими освітніми потребами тощо. 
Журнал «Герспективитаінноваціїнауки»

(Серія «Педагогіка», Серія «Гиихологія», Серія«Медицина»

№5(5) 2021

А скільки часу знадобиться на розробку конкретних механізмів та їх практичну реалізацію, оскільки питання залишається відкритим щодо можливостей фінансування інклюзивної освіти? На створення рівних умов для дітей 3 особливими освітніми потребами, починаючи 32018 р, в Україні виділено значне державне фінансування. Це означає, що кошти перераховуються 3 державного бюджету до місцевих бюджетів на оплату додаткових освітніх послуг, корекційно-розвиваючих заходів та придбання корекційного обладнання, визначеного відповідно до індивідуальної програми розвитку дитини. Однак ці програми не можуть забезпечити розв'язання питання про виховання в суспільстві толерантного ставлення до людей 3 обмеженими можливостями, а також схвалення реформи системи освіти 3 метою сприяння інклюзії. Поки реалізується Концепції «Нова українська школа», яка дозволить розпочати стратегію реформування середньої освіти до 2029 року. В концепцію закладено отримання вчителями нових компетенції; перетворення шкіл на дружнє місце для учнів, де їхня думка має значення, де їх вчать розвивати критичне мислення, не боючись висловлювати власну думку тощо. В основі Концепції лежить педагогіка партнерства: співпраці вчителя, учня та батьків, які мають стати рівноправними учасниками навчальновиховного процесу. Кожен учитель зможе працювати 3 дітьми 3 особливими освітніми потребами. Завдання стояло «розробити та запровадити обов'язковий для всіх педагогічних працівників курс щодо специфіки роботи 3 дітьми 3 особливими освітніми потребами в рамках інклюзивної освіти», що було внесено до Плану заходів на 2017-2029 роки щодо впровадження Нової української школи» і вже затверджено постановою Кабміну. [4, 5].

Ще одним важливим кроком, ініційованим Міністерством освіти та його партнерами, було створення інклюзивно-ресурсних центрів. Вже сьогодні створено 659 інклюзивно-ресурсних центрів, які покликані визначати особливі освітні потреби дітей не на основі міжнародної класифікації захворювань, як раніше, а на основі міжнародної класифікації функцій дітей $з$ особливими потребами. [6] Це набагато більш сучасний і менш дискримінаційний підхід. Крім того, ці центри територіально доступніші, оскільки створюються 3 розрахунку один центр на семи тисяч дітей (не більше), які проживають на території об'єднаної територіальної громади (району), та не більше як на 12 тисяч дітей, які проживають на території об'єднаної територіальної громади (району), у місті (районі міста).

Дійсно, уряд та МОН провели велику роботу щодо формування законодавчої бази для підтримки інклюзивної освіти в Україні. Застарілі психомедичні та освітні консультаційні центри по всій країні почали перетворюватися на сучасні інклюзивно-ресурсні центри, які підтримують дітей 3 особливими освітніми потребами. В інклюзивно-ресурсні центри подано 252634 заяв, створено 7612 установ [6]

Однак, відсутні закони, які б регулювали створення єдиної системи чи програми збору та узагальнення статистичних даних про кількість людей 3 
інвалідністю та їх потреби, необхідних для розробки та реалізації ефективних соціальних програм тощо. Залишаються лише опитування.

Опитування як батьків, які виховують дітей 3 особливими освітніми потребами, так і вчителів дозволило дослідникам уточнити коло проблем, які сьогодні існують у сфері інклюзивної освіти. І.Грабовець, Л.Калашнікова та Л.Чернова провели вельми цікаве дослідження. Батьки, відповідаючи на питання про прийнятну форму навчання для дітей, віддали перевагу денній формі навчання у навчальному закладі $(58,1 \%$ від загальної кількості респондентів). Майже кожен п'ятий респондент $(18,9 \%)$ схвалює індивідуальну форму, яка передбачає поєднання домашнього навчання та відвідування індивідуальних занять та заходів у навчальному закладі; 7,6\% батьків вважають доцільним використання заочної форми навчання, що передбачає індивідуальне дистанційне навчання без відвідування навчального закладу. Основним аргументом батьків, які виступають проти навчання своїх дітей у звичайних класах, групах навчальних закладів, $\epsilon$ те, що ці заклади не пристосовані до потреб їхніх дітей. За словами батьків, у загальноосвітніх навчальних закладах немає можливості отримати допомогу від помічника вчителя, вчителя (22,2\%), підтримки однолітків та їхніх батьків $(32,6 \%)$, вільно пересуватися в межах закладу (38,6\%), до відвідувати гуртки безкоштовно, секції/гуртки $(42,9 \%)$, відвідувати кабінет психологічної розвантаження $(49,1 \%)$. Крім того, опитані батьки вважають, що найбільш неприйнятні освітні програми $(13,6 \%)$, відсутність відповідної підготовки чи досвіду роботи 3 особливими дітьми у вчителів та вихователів (12,8\%) не запроваджені (або створені лише частково), ані відповідні умови доступності (10,0\%), відсутність належного фінансування школи $(7,9 \%)$, велика кількість дітей у шкільних класах, групах дитячого садка $(7,4 \%)$. Більшість батьків, які переживають складні життєві обставини, є недалекоглядними у планах щодо можливості продовження навчання для своїх дітей. Лише третина респондентів (31,8\%) відповіли на питання про перспективи отримання їх дітьми професійної освіти в майбутньому. Серед них 4,0\% зазначили, що їхні діти мають можливість i можливість продовжити навчання у закладах вищої освіти, 12,0\% - у ПТУ, технікумі, 4,0\% - у трудових майстернях. Решта 80\% лише припустили, що така можливість існує, але конкретних планів у них немає, тому вони не визначені остаточно у своїх відповідях. [7]

Якщо в інклюзивно-ресурсні центри подано 252634 заяв, а лише 4,0\% батьків - 10105 потенційних студентів мають можливість продовжувати навчання у закладах вищої освіти. Це свідчить по відсутність права у дітей на здобуття вищої освіти. Це є свідченням системної кризи. Ми не можемо одночасно запропонувати змінити умови навчання для студентів, змінити законодавство та вдосконалити інфраструктуру, створити комфортне інклюзивне середовище, проте ми замислилися над створенням умов для отримання освіти всім бажаючим: змінити цінності освіти.

Побудова моделі інклюзивного навчання в закладах вищої освіти, яка допоможе усім дітям, незалежно від етнічної та релігійної приналежності, стану здоров'я та інших відмінностей, почуватися комфортно та отримати високоякісну освіту є першочерговим завданням сьогодення. Слід зважити на те, що вона повинна мати не лише адаптивний, а й персоніфікований повноцінний характер. 


\section{Журнал«ГЕрспективита інновації наукиљ (Серія«Гедагогіка», Серія«ГТихологія», Серія«Медицина» №5(5) 2021}

\section{Освітні платформи онлайн курсів}

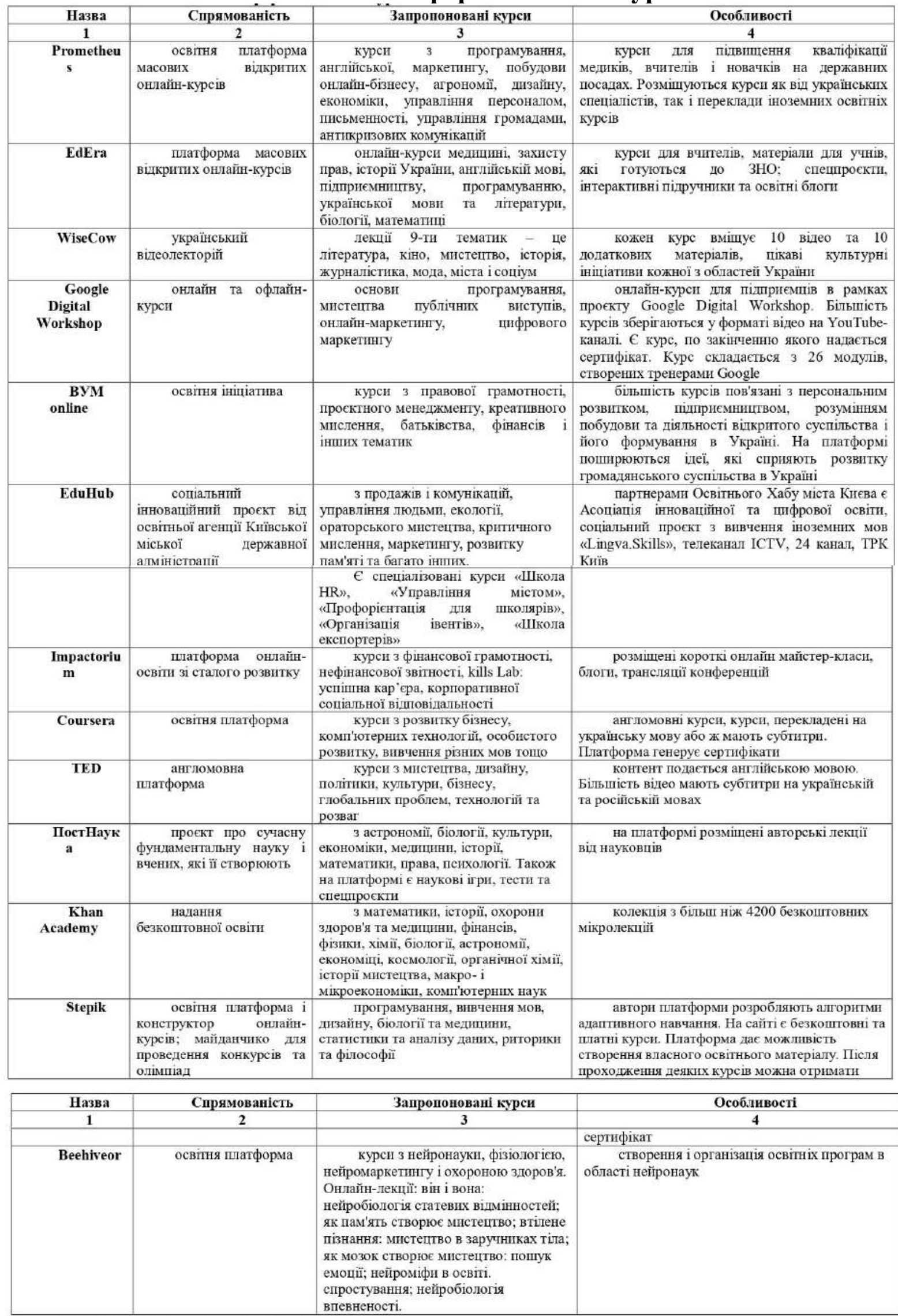


Перш ніж сформувати загальну концепцію та запропонувати модель ми проаналізували існуючі платформи, які допоможуть всім бажаючим долучитися до освітнього процесу (табл. 1).

Отже, ми бачимо 13 основних освітні онлайн платформ. Всі вони мають свою «спеціалізацію». Кожний розробник намагався посісти своє місце на освітньому ринку. Декілька платформ пропонують розміщувати з субтитрами або, як Google Digital Workshop, розміщують на YouTube-каналі. Останній також має функцію включення субтитрів. Stepik та EdEra використовують адаптивні технології. Ці технології дозволяють підвищити взаємодію з учнем та забезпечують індивідуальну підтримку. I ми знову зіткаємося 3 забезпеченням «інклюзивності» для дітей шкільного віку.

До таблиці 1 ми не включали ще одну платформу - «Всеукраїнська онлайн школа» [21], оскільки вона спрямована на учнів 5-11 класів. Ця платформа відповідає всім вимогам: 1) орієнтація на дітей шкільного віку; 2) навчальний контент відповідає чинним державним освітнім програмам; 3) діти можуть користуватися платформою як для навчання під час карантину, так i для ознайомлення 3 темою, яку пропустили у школі через хворобу або з інших причин; 4) для вчителів розроблені рекомендації для проведення змішаного та дистанційного навчання [21]. Платформа повністю відповідає вимогам, які висуваються до «інклюзивного навчання».

Однак на рівні вищої освіти майже відсутня пропозиція високоякісних онлайн платформ, які зможуть задовільнити прагнення всіх дітей здобути вищу освіту. Майже всі заклади вищої освіти використовують Moodle, Microsoft Teams, Zoom, Google classes тощо. На сьогоднішній день викладачі самі вирішують де проводити онлайн лекції, практичні заняття та тестування. Це не дозволяє студентам сконцентруватися на освіті, а витрачає їх час та енергію на комунікацію 3 викладачами через зручні для кожного з них веб-сервіси або програмне забезпечення. Крім того, викладачі, які розробляють курси, не враховують особливості дітей, які підпадають під категорію інклюзивності, а зазначені платформи не дозволяють комерціалізувати результати своїх розробок.

Більшість онлайн курсів були розроблені лише для розв'язання нагальної потреби: проведення занять під час локдауну. Інклюзивне навчання висуває підвищені вимогу для студентів та викладачів. Від студентів 3 ознаками інклюзії воно вимагає великої напруги сил - психологічних та інтелектуальних ресурсів особистості; від інших категорій студентів - розуміння, толерантності, готовності надавати допомогу та активно взаємодіяти з іншими, від викладачів, які працюють у таких групах, професіоналізму, спеціальних знань, особливих особистісних якостей, готовності та вміння співпрацювати. Одна з основних проблем - це відсутність єдиного стандарту в онлайн-освіті студентів. Сучасні суттєві зміни в суспільстві, спричинені викликами часу, пов'язані з активним розвитком інформаційних технологій. Проектування моделі інклюзивної освіти у ЗВО повинно бути направлено на усунення всебічних бар'єрів в 
інформаційно-освітньому середовищі. На даний момент спеціальні умови для адаптації студентів з інклюзією до ЗВО не створено, вони змушені самі долати бар'єри та адаптуватися до освітнього середовища.

При проєктуванні моделі інклюзивного навчання в ЗВО слід враховувати необхідність якісного супроводу студента на всіх етапах його навчання, в повній взаємодії з усіма стекголдерами освітнього процесу, та мати якісну методичну систему, що визначає цілі, зміст, форми, методи, засоби навчання, суб'єкти та партнери інклюзивної освіти. Отже, ми приходимо до реалізації всеукраїнської програми дистанційного навчання, яка має врахувати вимоги «інклюзивності» у закладах вищої освіти.

Модель, над якою ми працюємо, має зародковий характер. В основі нашої моделі ми заклали онлайн освітню платформу з розробленим функціоналом та адаптованими онлайн курсами під сучасні потреби студентів, у тому числі 3 використанням адаптивних технологій. Кожен студент зможе навчатися у зручний для нього час, спілкуватися зі своїми друзями та викладачами у спільних відео-сесіях та брати участь в онлайн конференціях, повторно переглядати відео-лекції тощо.

Онлайн освітня платформа дозволить сформувати єдиний освітній стандарт за рахунок створеного комфортного середовища та спеціально розробленої методології для отримання максимальних результатів від навчання студентів онлайн.

Розробляючи платформу ми закладаємо певні особливості, які формують переваги у порівнянні з іншими існуючими платформами:

1. Турбота про здоров'я. Під час пандемії важливо не зловживати громадськими місцями. Онлайн освітня платформа дозволить мінімізувати ризики зараження та максимізує результативність навчання;

2. Турбота про час. Час - найцінніший ресурс. Студент зможе навчатися у будь-який зручний для нього час;

3. Турбота про екологію. Мінімізуємо друк інформації, підручників, тестів тощо;

4. Благодійність. Кожен користувач отримає 5\% доступу до будь-якого онлайн-курсу абсолютно безкоштовно;

5. Багатомовленнєвість. Створення комфортного середовища для використання освітнього контенту 3 метою персоналізації навчання кожного користувача онлайн платформи;

6. Спеціальні можливості. Ряд розробленого функціоналу платформи дозволить користувачам, у тому числі й 3 особливими птребами, засвоювати освітній контент зручним для них способом: озвучка тексту, голосове управління, масштабування контенту та зміна кольорової теми зовнішнього вигляду платформи для максимальної персоналізації; 
7. Мікросервісна архітектура. Розподіл навантаження на сервери для простішого масштабування та подальшої розробки. Це забезпечить стабільну роботу онлайн платформи для користувачів та витримає навантаження у 100 разів більше, ніж ресурси із стандартними монолітними архітектурами;

8. Конфіденційність та безпека. Сучасні методи шифрування дозволять захистити особисті дані користувачів від третіх осіб.

Розробка нової онлайн платформи спрямована на зміцнення ідеї та практики інклюзивної освіти, що, в свою чергу, сприятиме формуванню та розвитку спільноти освітян-активістів, які поширюють інклюзивне розуміння освітнього процесу та права всіх на рівну освіту, які вже крок за кроком входять у практику освітнього життя України. Ми пропонуємо відчуття безпеки та приналежності до колективу. Студенти зможуть брати участь в процесі визначення освітніх цілей та індивідуальних освітніх траєкторій, поєднуючи формальну та неформальну освіту та очікуючи на належний рівень підтримки, гнучкості та заохочення.

Наша мета - побудувати відкрите інклюзивне суспільство в Україні, без обмежень в віці від 2-х до 18-ти років. Для цього ми запускаємо власний проєкт, якій дозволить кожному реалізувати право на освіту, право розвиватися, працювати та жити якомога значніше.

Висновки. Відсутність статистичної бази, яка б дозволила визначити групи дітей, які підпадають під категорію «інклюзивності». Єдиним інструментом залишається соціологічне опитування, яке дозволяє виявити кількість дітей $з$ особливими потребами, які мають бажання отримати вищу освіту, готовність батьків підтримувати своїх дітей на шляху до їх прагнень. Відсутність будь-якої моделі інклюзивного навчання в закладах вищої освіти стала каталізатором у наших розробках та допомогла сформувати концепцію нової онлайн платформи. Перш ніж ми сформувати загальну концепцію та запропонувати модель, нами були проаналізовано онлайн платформи представлені на українському освітньому ринку. Наші платформи не представляють заклади вищої освіти, не містять вимог до «інклюзивності», не дозволяють комерціалізувати результати своїх розробок. Нова онлайн платформа - це новий стандарт освітніх онлайн послуг; це реалізація однієї 3 цілей сталого розвитку; це зміцнення ідеї та практики інклюзивної освіти.

Звичайно тема $\epsilon$ міждисциплінарною i потребує наших подальших досліджень. Аналіз найкращих світових практик та адаптивних навчальних інструментів дозволить використати їх при наповнені нової платформи та поширити наші новації серед освітянської спільноти.

Jimepamypa:

1. Конвенція про права осіб 3 інвалідністю // https://zakon.rada.gov.ua/laws/show/ 995_g71\#Text

2. Розпорядження Кабінету Міністрів України «Про затвердження планів заходів щодо впровадження інклюзивної та інтегрованої освіти в загальноосвітніх навчальних закладах на 
період до 2012 року» від від 3 грудня 2009 p. №1482-p// https://zakon.rada.gov.ua/ laws/show/1482-2009-\%D1\%80\#Text

3. Наказ МОН «Про затвердження плану заходів щодо впровадження інклюзивної освіти в загальноосвітніх навчальних закладах на 2009-2012 роки» від 11.09.2009 № 855 // https://zakon.rada.gov.ua/rada/show/v0855290-09\#Text

4. Постанова Кабінету Міністрів України «Про затвердження Порядку організації інклюзивного навчання у загальноосвітніх навчальних закладах» від 15 серпня 2011 р. № 872 // https://zakon.rada.gov.ua/laws/show/872-2011-\%D0\%BF\#Text

5. Розпорядження Кабінету Міністрів України «Про затвердження плану заходів на 2017-2029 роки із запровадження Концепції реалізації державної політики у сфері реформування загальної середньої освіти «Нова українська школа» від 13 грудня 2017 р. № 903-p // https://zakon.rada.gov.ua/laws/show/903-2017-\%D1\%80\#Text

6. Офіційний сайт інклюзивно-ресурсних центів // https://ircenter.gov.ua/

7. Hrabovets I., Kalashnikova L., Chernou L. The problems of implementation of inclusive education in Ukraine: generalization the experience of empirical sociological researches experience// SHS W eb of Conferences 75, 03011 (2020). 26 March 2020// https://doi.org/10.1051/shsconf/20207503011

8. Офіційний сайт освітньої платформи Prometheus //https://prometheus.org.ua/

9. Офіційний сайт студії онлайн освіти EdEra // https://www.ed-era.com/

10. Офіційний сайт українського відеолекторія // WiseCow https://wisecow.com.ua/

11. Офіційний сайт //https://learndigital.withgoogle.com/digitalworkshop-ua/courses

12. Офіційний сайт онлайн платформи ВУМ online // https://vumonline.ua/

13. Офіційний сайт онлайн платформи EduHub // https://eduhub.in.ua/courses

14. Офіційний сайт онлайн платформи Impactorium // https://impactorium.org/uk/allcourses/

15. Офіційний сайт онлайн платформи Coursera // https://www.coursera.org/

16. Офіційний сайт онлайн платформи TED // https://www.ted.com/talks?language=ru

17. Офіційний сайт онлайн платформи ПостНаука // https://postnauka.ru/

18. Офіційний сайт онлайн платформи Khan Academy // https://ru.khanacademy.org/

19. Офіційний сайт онлайн платформи Stepik // https://stepik.org/catalog

20. Офіційний сайт онлайн платформи Beehiveor // https://training.academy/uk/beehiveor

21. Всеукраїнська онлайн школа https://nus.org.ua/news/v-ukrayini-zapustyly-elektronnuosvitnyu-platformu/

\section{References:}

1. Konventsiya pro prava osib z invalidnistyu [Convention on the Rights of Persons with Disabilities] // https://zakon.rada.gov.ua/laws/show/995_g71\#Text (in Ukrainian)

2. Rozporyadzhennya Kabinetu Ministriv Ukrayiny «Pro zatverdzhennya planiv zakhodiv shchodo vprovadzhennya inklyuzyvnoyi ta intehrovanoyi osvity v zahal'noosvitnikh navchal'nykh zakladakh na period do 2012 roku» vid vid 3 hrudnya 2009 r. №1482-r [Order of the Cabinet of Ministers of Ukraine "On approval of action plans for the implementation of inclusive and integrated education in secondary schools for the period up to 2012" from December 3, 2009 №1482-y]// https://zakon.rada.gov.ua/laws/show/1482-2009-\%D1\%80\#Text (in Ukrainian)

3. Nakaz MON «Pro zatverdzhennya planu zakhodiv shchodo vprovadzhennya inklyuzyvnoyi osvity v zahal'noosvitnikh navchal'nykh zakladakh na 2009-2012 roky» vid 11.09.2009 № 855 [Order of the Ministry of Education and Science "On approval of the action plan for the implementation of inclusive education in secondary schools for 2009-2012" dated 11.09.2009 № 855]// https://zakon.rada.gov.ua/rada/show/v0855290-09\#Text (in Ukrainian) 
4. Postanova Kabinetu Ministriv Ukrayiny «Pro zatverdzhennya Poryadku orhanizatsiyi inklyuzyvnoho navchannya u zahal'noosvitnikh navchal'nykh zakladakh» vid 15 serpnya $2011 \mathrm{r}$. № 872 [Resolution of the Cabinet of Ministers of Ukraine "On approval of the Procedure for the organization of inclusive education in secondary schools" of August 15, 2011 № 872]// https://zakon.rada.gov.ua/laws/show/872-2011-\%D0\%BF\#Text (in Ukrainian)

5. Rozporyadzhennya Kabinetu Ministriv Ukrayiny «Pro zatverdzhennya planu zakhodiv na 2017-2029 roky iz zaprovadzhennya Kontseptsiyi realizatsiyi derzhavnoyi polityky u sferi reformuvannya zahal'noyi seredn'oyi osvity «Nova ukrayins'ka shkola» vid 13 hrudnya 2017 r. № 903-r [rder of the Cabinet of Ministers of Ukraine "On approval of the action plan for 2017-2029 to implement the Concept of implementation of state policy in the field of reforming general secondary education" New Ukrainian School "of December 13, 2017 № 903-y] // https://zakon.rada.gov.ua/laws/show/903-2017-\%D1\%80\#Text (in Ukrainian)

6. Ofitsiynyy sayt inklyuzyvno-resursnykh tsentiv [Official site of inclusive resource centers]// https://ircenter.gov.ua/(in Ukrainian)

7. Hrabovets I., Kalashnikova L., Chernou L. The problems of implementation of inclusive education in Ukraine: generalization the experience of empirical sociological researches experience// SHS Web of Conferences 75, 03011 (2020). 26 March 2020// https://doi.org/10.1051/ shsconf/20207503011 (in English)

8. Ofitsiynyy sayt osvitn'oyi platformy Prometheus [Official site of the educational platform Prometheus] //https://prometheus.org.ua/ (in Ukrainian)

9. Ofitsiynyy sayt studiyi onlayn osvity EdEra [Official site of the online education studio EdEra] // https://www.ed-era.com/ (in Ukrainian)

10. Ofitsiynyy sayt ukrayins'koho videolektoriya [Official site of the Ukrainian video lecture] // WiseCow https://wisecow.com.ua/ (in Ukrainian)

11. Ofitsiynyy sayt Ukrayins'ka komanda Google [Official site of the Ukrainian Google team] //https://learndigital.withgoogle.com/digitalworkshop-ua/courses (in Ukrainian)

12. Ofitsiynyy sayt onlayn platformy VUM online [Official site of the online platform VUM online] // https://vumonline.ua/ (in Ukrainian)

13. Ofitsiynyy sayt onlayn platformy EduHub [Official site of the online platform EduHub]// https://eduhub.in.ua/courses (in Ukrainian)

14. Ofitsiynyy sayt onlayn platformy Impactorium[Official site of the online platform Impactorium] // https://impactorium.org/uk/all-courses/ (in Ukrainian)

15. Ofitsiynyy sayt onlayn platformy Coursera [Official site of the online platform Courser]// https://www.coursera.org/ (in Ukrainian)

16. Ofitsiynyy sayt onlayn platformy TED [Official site of the online TED platform] // https://www.ted.com/talks?language=ru (in Russia)

17. Ofitsiynyy sayt onlayn platformy PostNauka [Official site of the online platform PostNauka] https://postnauka.ru/ (in Russia)

18. Ofitsiynyy sayt onlayn platformy Khan Academy [Official site of the online platform Khan Academy] // https://ru.khanacademy.org/ (in Russia)

19. Ofitsiynyy sayt onlayn platformy Stepik [Official site of the online platform Stepik] // https://stepik.org/catalog (in Ukrainian)

20. Ofitsiynyy sayt onlayn platformy Beehiveor [Official site of the online platform Beehiveor] // https://training.academy/uk/beehiveor (in Ukrainian)

21. Vseukrayins'ka onlayn shkola [Ukrainian online school] https://nus.org.ua/news/vukrayini-zapustyly-elektronnu-osvitnyu-platformu/ (in Ukrainian) 